\title{
INVENTARISASI JENIS-JENIS LUMUT DI KAWASAN HUTAN ADAT BUKIT BENUAH KABUPATEN KUBU RAYA
}

\author{
Shela Erika Putri, Hari Prayogo, Reine Suci Wulandari \\ Fakultas Kehutanan Universitas Tanjungpura Pontianak. Jl. Daya Nasional Pontianak 78124 \\ Email : shelaerikaputri@gmail.com
}

\begin{abstract}
Moss is a group of small plants that grow attached to various types of substrate, moss life is influenced by environmental factors such as temperature, humidity and light. This study aims to obtain data on the types of moss and climatic conditions in the Bukit Benuah Sungai Ambawang Customary Forest area of Kubu Raya Regency which is located in the Bukit Benuah Sungai Ambawang Customary Forest area of Kubu Raya Regency. This research was conducted for 3 months. The research uses the roaming or exploration method, which is exploring and observing the area of the research location with the number of plots as many as 3 observation plots. Sampling and collection using the touch point method in getting the types that have been sampled. There were 7 species of lichens, Brachymenium indicum, Dicranella sp, Sphagnum sp, Jungermannia sp, Monoclea forsteri, Lepraria incana, and Parmelia sp. There are 3 types of moss plants that dominate, namely Brachymenium indicum and Sphagnum sp from leaf moss and Jungermannia sp from liverworts. Environmental conditions that support the growth of moss in the Benuah Hill customary forest area are at a temperature of $21^{\circ}-23^{\circ} \mathrm{C}$, the intensity of the incoming light is $52 \%-206 \%$ and the humidity level is $78 \%-83 \%$.
\end{abstract}

Keyword: Inventory, Moss, Benuah Hill.

\section{PENDAHULUAN}

Hutan adat merupakan hutan yang berada dalam wilayah hukum masyarakat adat, pengertian hutan adat mengacu kepada status kawasan hutan itu sendiri, serta hak ulayat atau hak tradisionalnya berkedudukan khusus (lex specialis) dan berlaku hukum adat sesuai dengan pasal 5 undang-undang pokok agraria (UUPA) yang berarti "hak menguasai negara tidak berlaku dalam yuridiksi hak masyarakat hukum adat beserta hak ulayat atau hak tradisional lainnya, sekalipun hubungan fungsional keduanya tetap dimungkinkan dapat diatur sendiri. Kawasan hutan adat Bukit Benuah tumbuh berbagai macam tumbuhan seperti pohon, tumbuhan bambu, tumbuhan herba dan juga berbagai macam tumbuhan bawah salah satunya adalah tumbuhan lumut yang termasuk ke dalam tumbuhan bawah.

Tumbuhan bawah adalah komunitas tanaman yang menyusun stratifikasi bawah dekat permukaan tanah, tumbuhan ini umumnya berupa rumput, herba, semak atau perdu rendah. Jenis-jenis vegetasi ini ada yang bersifat annual, biannual atau perenial. Tumbuhan bawah banyak dimanfaatkan masyarakat desa hutan untuk memenuhi kebutuhan hidup sehari-hari seperti untuk memelihara kesehatan dan 
pengobatan berbagai macam penyakit (Nirwani, 2011). Salah satu tumbuhan bawah yang banyak ditemukan pada kawasan Hutan Adat Bukit Benuah yaitu tumbuhan lumut.

Penelitian ini bertujuan untuk mendapatkan data tentang keberadaan jenis-jenis lumut yang berada didalam kawasan Hutan Adat Bukit Benuah Sungai Ambawang Kabupaten Kubu Raya serta kondisi iklim lingkungan seperti suhu, intensitas cahaya dan kelembaban pada habitat yang di tumbuhi oleh lumut.

\section{METODE PENELITIAN}

Penelitian di kawasan Hutan Adat Bukit Benuah Sungai Ambawang Kabupaten Kubu Raya selama 3 bulan. Objek penelitian adalah jenis-jenis lumut. Alat-alat yang digunakan dalam penelitian adalah GPS, Higrometer, Lup, alat pengukur intensitas cahaya, ATK, plastik spesimen untuk menyimpan sampel lumut, kamera, pisau kecil/gunting, buku identifikasi berfungsi untuk memberikan pengenalan terhadap setiap jenis lumut berdasarkan habitat dan morfologi dari setiap jenis lumut, meteran/tali berfungsi untuk membuat plot yang didalamnya berisikan panjang dan luas suatu plot pada lokasi penelitian, kawat atau tali plastik sepanjang $10 \mathrm{~cm}$, kayu sepanjang $1 \times 1 \mathrm{~m}$ dan paku berfungsi untuk membuat pola kisi dan metode kuadrat dalam metode titik sentuh.

Metode penelitian yang digunakan metode eksplorasi/menjelajah menurut Damayanti (2006), pengambilan dan pengumpulan sampel dilakukan dengan menggunakan metode purposive sampling yaitu pengambilan sampel secara sengaja tetapi berdasarkan tujuan penelitian yang dimaksudkan dengan pertimbangan tertentu dan dengan menggunakan metode titik sentuh dalam mendapatkan jenis yang telah dijadikan sampel.

Langkah-langkah dalam operasional metode titik sentuh atau pola kisi sebagai berikut:

1. Alat yang berupa kerangka besi atau kayu dengan tongkat jarum penunjuk diletakkan menyentuh permukaan tumbuhan yang akan dianalisis dan pindahkan alat tersebut sesuai dengan luasan yang diamati.

2. Sebagai satuan contoh pengamatan adalah interval yang terdiri dari 10 lubang atau panjang 10 meter.

3. Jenis tumbuhan yang tersentuh oleh tongkat atau jarum penunjuk, dicatat jumlah intervalnya sebagai satuan pengamatan.

4. Data hasil pengukuran selanjutnya dianalisis untuk memperoleh nilai frekuensi dan dominansi jenis lumut.

Analisis data dilakukan secara deskritif kuantitatif dengan melihat bentuk morfologi dari masing-masing jenis lumut. Pengolahan data hasil pengukuran dan pengamatan tumbuhan lumut menurut (Damayanti, 2006) dilakukan dengan menghitung Dominansi Mutlak (DM), Dominansi Relatif (DR), Frekuensi Mutlak (FM), Frekuensi Relatif (FR), Indeks Nilai 
Penting (INP), Dominansi (C),

Keanekaragaman Jenis $\left(\mathrm{H}^{\prime}\right)$.

Frekuensi

$=\frac{\text { Frekuensi Mutlak Jenis } i}{\text { Total Frekuensi Seluruh Jenis } i} \times 100 \%$

Dominasi Relatif

$=\frac{\text { Dominasi Mutlak Jenis } i}{\text { Total Dominasi Seluruh Jenis } i} \times 100 \%$

Indeks Nilai Penting $=$ FR + DR

Dominasi $(\mathrm{C})=\Sigma \frac{n i^{2}}{N}$

Indeks Keanekaragaman

$\mathrm{H}^{\prime}=-\sum \frac{n i}{N} \log \frac{n i}{N}$
HASIL DAN PEMBAHASAN

Hasil inventarisasi dari lokasi penelitian ditemukan sebanyak 7 jenis lumut. Jenis tanah pada plot I, 2 dan 3 yaitu podsolik merah kuning dengan struktur hutannya didominasi oleh pepohonan serta ketinggian tempat pada plot I yaitu $165 \mathrm{mdpl}$, pada plot 2 ketinggian tempat $170 \mathrm{mdpl}$ dan pada plot 3 ketinggian tempat $175 \mathrm{mdpl}$. Jenis-jenis lumut yang ditemukan pada plot pengamatan berdasarkan habitat tumbuhnya disajikan pada tabel 1 .

Tabel 1. Jenis-jenis Lumut yang ditemukan pada plot pengamatan berdasarkan habitat tumbuhnya (Types Of Mosses Found In The Observation Plot Based On Habitat Growth)

\begin{tabular}{|c|c|c|c|c|c|c|c|c|}
\hline \multirow{2}{*}{ No } & \multirow{2}{*}{ Kelas } & \multirow{2}{*}{ Family } & \multirow{2}{*}{ nama jenis } & \multicolumn{3}{|c|}{ Plot } & \multirow{2}{*}{ jumlah } & \multirow{2}{*}{ Substrat } \\
\hline & & & & 1 & 2 & 3 & & \\
\hline 1 & $\begin{array}{l}\text { Lumut daun } \\
\text { (Musci) }\end{array}$ & Bryaceae & $\begin{array}{l}\text { Brachymenium } \\
\text { indicum }\end{array}$ & 194 & 0 & 0 & 194 & $\begin{array}{l}\text { kayu } \\
\text { lapuk }\end{array}$ \\
\hline 2 & $\begin{array}{l}\text { Lumut daun } \\
\text { (Musci) }\end{array}$ & Dicranaceae & Dicranella sp & 16 & 0 & 0 & 16 & Batu \\
\hline 6 & $\begin{array}{l}\text { Lumut daun } \\
\text { (Musci) }\end{array}$ & Sphagnaceae & Sphagnum sp & 0 & 0 & 194 & 194 & Batu \\
\hline 3 & $\begin{array}{l}\text { Lumut hati } \\
\text { (Hepaticeae) }\end{array}$ & Jungermanniaceae & $\begin{array}{l}\text { Jungermannia } \\
\text { sp }\end{array}$ & 0 & 189 & 0 & 189 & Batu \\
\hline 4 & $\begin{array}{l}\text { Lumut hati } \\
\text { (Hepaticeae) }\end{array}$ & Monocleaceae & $\begin{array}{l}\text { Monoclea } \\
\text { forsteri }\end{array}$ & 0 & 17 & 0 & 17 & Pohon \\
\hline 5 & $\begin{array}{l}\text { Lumut kerak } \\
\text { (Lichen) }\end{array}$ & Stereocaulaceae & $\begin{array}{l}\text { Lepraria } \\
\text { incana }\end{array}$ & 0 & 22 & 0 & 22 & Batu \\
\hline 6 & $\begin{array}{l}\text { Lumut kerak } \\
\text { (Lichen) }\end{array}$ & Parmeliaceae & Parmelia sp & 0 & 0 & 26 & 26 & Pohon \\
\hline
\end{tabular}

Tabel 1 menunjukkan bahwa pada plot I dengan ketinggian tempat $165 \mathrm{mdpl}$ terdapat 2 jenis lumut dari kelas lumut daun yang terbagi atas famili dan jenis yang berbeda yaitu jenis Brachymenium indicum yang mendominasi dan Dicranella sp. Jumlah individu dari family Bryaceae (Brachymenium indicum) sebanyak 194 individu dengan substart menempel pada kayu lapuk, sedangkan family dari Dicranaceae (Dicranella $\mathrm{sp}$ ) sebanyak 16 individu dengan substrat menempel pada batu, sehingga dapat disimpulkan dari antara kedua jenis lumut tersebut bahwa pada plot 1 individu yang dominan adalah dari famili Bryaceae (Brachymenium indicum) yang menempel atau tumbuh pada kayu lapuk. Windadri (2010) menyatakan bahwa pada batang kayu yang sudah lapuk merupakan media 
atau tempat yang baik bagi pertumbuhan lumut karena kayu yang sudah lapuk banyak menyerap atau menyimpan air di antara sel-sel kayunya sehingga memiliki kelembaban yang tinggi dan zat-zat yang diperlukan oleh tumbuhan lumut untuk menunjang pertumbuhannya.

Pada plot II dengan ketinggian tempat 170 mdpl ditemukan 3 jenis lumut dengan jumlah individu yang berbeda yaitu jenis Jungermannia sp, Monoclea forsteri dan Lepraria incana. Family Jungermaniaceae (Jungermannia sp) berjumlah 189 individu dengan substart menempel pada batu, kemudian jumlah individu dari famili Stereocaulaceae (Lepraria incana) sebanyak 22 individu dengan substrat menempel pada batu dan jumlah individu dari famili Monocleaceae (Monoclea forsteri) sebanyak 17 individu dengan substrat menempel pada pohon. Pada plot ini ditemukan jenis lumut yang dominan yaitu Jungermannia sp yang menempel atau tumbuh pada substrat batu.

Pada plot III dengan ketinggian tempat 175 mdpl ditemukan dua jenis lumut dengan individu yang berbeda yaitu Sphagnum sp dari family (Sphagnaceae) dan Parmelia $s p$ dari famili (Parmeliaceae), pada plot ini jenis lumut yang mendominasi yaitu Sphagnum sp dengan jumlah individu sebanyak 194 individu dengan substrat yang menempel pada batu. Berdasarkan hasil penelitian jenis-jenis lumut yang ditemukan dalam setiap plot berdasarkan substrat yang telah disajikan pada tabel 1 , diperoleh data jenis lumut yang paling mendominasi dari keseluruhan plot yaitu kelas lumut daun dengan 2 jenis yang berbeda serta substrat yang berbeda. Lumut daun jenis Brachymenium indicum dari famili Bryaceae (lumut daun) dengan jumlah 194 individu pada plot I yang menempel pada kayu lapuk, dan pada plot 3 ditemukan juga jenis lumut yang mendominasi yaitu Sphagnum sp dari famili Sphagnaceae dengan jumlah yang sama yaitu 194 individu yang menempel pada batu.

Menurut pendapat Febrianti (2015) pertumbuhan lumut dapat dipengaruhi oleh faktor biotik dan abiotik seperti suhu dan kelembaban serta dipengaruhi oleh faktor ketinggian tempat, iklim dan ketersediaan unsur hara yang mempengaruhi tingkat dominansi pertumbuhan lumut. Hal ini juga ditegaskan oleh Pasaribu (2013) bahwa tumbuhan lumut banyak tumbuh pada tutupan kanopi yang rapat dan kelembaban yang tinggi. Hal inilah yang menyebabkan jenis-jenis lumut Brachymenium indicum dan Sphagnum sp tumbuh dominan pada keseluruhan plot penelitian dengan ratarata tingkat suhu, kelembaban udara dan intensitas cahaya pada semua plot yaitu suhu $22^{\circ} \mathrm{C}$, kelembaban udara $80,66 \%$ dan intensitas cahaya yang masuk sebanyak 77,34\%. Indrawan et al (2007) menyatakan bahwa ketinggian tempat bersama faktor lain seperti iklim dan ketersediaan unsur hara akan menentukan kekayaan spesies pada tingkat habitat. 
Tabel 2. Hasil Perhitungan Data Jenis-Jenis Lumut Menggunakan Rumus Domiansi Mutlak (DM), Dominansi Relatif (DR), Frekuensi Mutlak (FM), Frekuensi Relatif (FR), Indeks Nilai Penting (INP), Indeks Dominansi (C), Keanekaragaman Jenis (H) (Recapitulation Of Absolute Dominance value (DM), Relative Dominance (DR), Absolute Frequency (FM), Relative Frequency (FR), Important Value Index (INP), Dominance Index (C), Species Diversity (H'))

\begin{tabular}{|c|c|c|c|c|c|c|c|c|c|c|c|}
\hline Plot & & Kelas & Jenis & DM & DR & FM & FR & INP & $\begin{array}{c}\text { Indeks } \\
\text { Domin } \\
\text { ansi }\end{array}$ & $\begin{array}{l}\text { Keaneka } \\
\text { ragaman } \\
\text { Jenis }\end{array}$ & $\begin{array}{c}\text { H' (total) } \\
\text { plot }\end{array}$ \\
\hline \multirow{2}{*}{ I } & 1 & $\begin{array}{l}\text { Lumut } \\
\text { Daun }\end{array}$ & $\begin{array}{l}\text { Brachymenium } \\
\text { indicum }\end{array}$ & 194 & 92,38 & 0,72 & 85,71 & 178,10 & 0,80 & 0,3601 & \multirow{2}{*}{0,4505} \\
\hline & 2 & $\begin{array}{l}\text { Lumut } \\
\text { daun }\end{array}$ & Dicranella $s p$ & 16 & 7,62 & 0,12 & 14,28 & 21,90 & 0,01 & 0,0904 & \\
\hline \multirow{3}{*}{ II } & 3 & $\begin{array}{l}\text { Lumut } \\
\text { hati }\end{array}$ & $\begin{array}{l}\text { Jungermannia } \\
s p\end{array}$ & 189 & 82,89 & 0,52 & 61,90 & 144,80 & 0,70 & 0,3583 & \multirow{3}{*}{0,5664} \\
\hline & & $\begin{array}{l}\text { Lumut } \\
\text { hati }\end{array}$ & $\begin{array}{l}\text { Monoclea } \\
\text { forsteri }\end{array}$ & 17 & 7,46 & 0,16 & 19,04 & 26,50 & 0,01 & 0,0945 & \\
\hline & 5 & $\begin{array}{l}\text { Lumut } \\
\text { kerak }\end{array}$ & Lepraria incana & 22 & 9,65 & 0,2 & 23,80 & 33,50 & 0,02 & 0,1136 & \\
\hline \multirow{2}{*}{ III } & 6 & $\begin{array}{l}\text { Lumut } \\
\text { daun }\end{array}$ & Sphagnum sp & 194 & 92,38 & 0,72 & 85,71 & 178,10 & 0,80 & 0,3601 & \multirow{2}{*}{0,4878} \\
\hline & 7 & $\begin{array}{l}\text { Lumut } \\
\text { kerak }\end{array}$ & Parmelia $s p$ & 26 & 12,38 & 0,12 & 14,29 & 26,67 & 0,01 & 0,1277 & \\
\hline \multicolumn{4}{|c|}{ Jumlah } & 658 & & & & & & 1,5046 & \\
\hline
\end{tabular}

Hasil perhitungan jumlah jenis-jenis lumut yang mendominasi dari setiap plot yang disajikan pada Tabel 2, hasil rekapitulasi perhitungan data menunjukkan bahwa nilai terbesar dari jumlah dominansi jenis-jenis lumut nilai yang paling mendominasi dari seluruh jenis yaitu jenis Brachymenium indicum dan Sphagnum sp, keduanya berasal dari kelas lumut daun dengan substrat tumbuh pada kayu lapuk dan batu. Pada perhitungan INP jenis Brachymenium indicum sebesar 178,10 tingkat dominansi (C) sebesar 0,80. Kemudian jenis lumut Sphagnum sp memperoleh hasil perhitungan INP sebesar 178,10, tingkat dominansi (C) sebesar 0,80 dan jumlah perhitungan indeks keanekaragaman jenis ( $\mathrm{H}^{\prime}$ total) sebesar 0,487766. Hasil yang diperoleh dari perhitungan pada indeks nilai penting (INP) jenis Bracymenium indicum dan sphagnum $s p$ keduanya mendapatkan jumlah hasil yang sama yaitu sebesar 178,10 yang termasuk dalam kategori sedang (S), hal ini dipengaruhi oleh faktor biotik dan abiotik serta keadaan lingkungan struktur hutan yang ada di sekitar plot dalam lokasi penelitian di dominasi oleh pepohonan sehingga kedua lumut ini tumbuh dominan dengan tingkat keanekaragaman jenisnya lebih tinggi dibandingkan dari jenis lumut lainnya yang berada dalam plot penelitian hutan adat Bukit Benuah. Hal ini sejalan dengan hasil penelitian Indrawan et al (2007) menyatakan bahwa ketinggian tempat bersama faktor 
lain seperti iklim dan ketersediaan unsur hara akan menentukan kekayaan spesies pada tingkat habitat.

\section{Jenis-Jenis Lumut Di Kawasan Hutan Adat Bukit Benuah Kabupaten Kubu Raya}

\section{Lumut Daun (Musci)}

a . Brachymenium indicum

Klasifikasi Brachymenium indicum

Kerajaan : Plantae

Divisi : Bryophyta

Kelas : Bryopsida

ordo : Bryales

Famili : Bryaceae

Genus : Brachymenium

Spesies : Brachymenium indicum

Jenis lumut ini banyak terdapat di daerah pegunungan Indonesia. Lumut sejati ini tumbuh dalam populasi pada batang pohon, tetapi dalam penelitian ini tumbuh pada substrat kayu lapuk atau batu. Talus tumbuh tegak dengan ukuran pendek, daun berwarna hijau dengan bentuk lanset berujung lancip dan tumbuh secara meroset, pada ujung talus daun lebih banyak tumbuh. Lumut ini berumah dua terdapat lumut dengan gametofit jantan yang memiliki anteridium serta lumut bergametofit betina dengan arkegoniumnya. Akregonium yang terserbuki oleh sperma dari anteridium akan tumbuh menjadi lumut sporofit. Lumut sporofit akan mengeluarkan seta dengan kapsul spora di ujungnya, kapsul spora berdiri tegak dan bila sudah masak akan mengeluarkan atau menyebarkan spora-sporanya. Spora yang jatuh di tempat yang cocok akan tumbuh menjadi lumut gametofit baru. Brachymenium indicum tumbuh secara tersusun dan tampak seperti bintang jika dilihat dari bagian atas (dorsal), memiliki ukuran yang sangat kecil dengan panjang berkisar 1-3 mm, batang pada lumut ini sangat pendek dan tertutupi oleh daun sehingga batangnya tidak terlihat, daun berwarna hijau muda, susunan daun berselang-seling dan sangat rapat tampak seperti menumpuk dan bentuk daun dari spesies ini memanjang, tepi daun rata dan ujung daunnya meruncing. Perkembangbiakan lumut ini dilakukan secara vegetatif dilakukan dengan umbi dari rizoid dan dengan adanya kuncup (gemmae). Kuncup yang terlepas atau patah akan menumbuhkan talus baru dari rizoid sehingga tumbuh menjadi lumut bergametofit baru. Selain di Indonesia, jenis lumut ini tedapat juga di Amerika Serikat, Amerika Tengah dan Selatan (Chili), Asia Tenggara, Papua Nugini, Kepulauan Fiji, Kepulauan Mikronesia dan Australia (Suhono et al, 2012).

b. Dicranella $s p$

Klasifikasi Dicranella sp

Kerajaan : Plantae

Divisi : Bryophyta 


$\begin{array}{ll}\text { Kelas } & : \text { Bryopsida } \\ \text { Ordo } & : \text { Bryales } \\ \text { Famili } & : \text { Dicranaceae } \\ \text { Genus } & : \text { Dicranella } \\ \text { Spesies } & : \text { Dicranella } \mathrm{sp}\end{array}$

Jenis lumut dari famili dicranaceae tumbuh pada daerah yang tinggi seperti di pegunungan contohnya pada tanah yang terbuka, kayu lapuk dan batuan yang bersifat asam. Kemampuan jenis-jenis lumut dari famili dicraneceae untuk mampu hidup dengan baik dalam kondisi habitat dengan keasaman yang tinggi dan tumbuh dengan penyebaran yang luas (kosmopolitan) jarang ditemukan dengan spora sehingga memungkinkan famili ini lebih mengutamakan perkembangan secara vegetatif, reproduksi secara vegetatif cenderung lebih sukses mengkolonisasi wilayah lebih luas daripada dengan spora. Lumut anggota dicranaceae umumnya tumbuh di lantai hutan dengan ketinggian 1000 mdpl (Windadri, 2014). Tetapi dari hasil penelitian ini jenis lumut dari famili Dicranaceae tumbuh di lantai hutan dengan ketinggian $165 \mathrm{mdpl}$, oleh sebab itu tingkat pertumbuhan atau dominansi pada lumut ini lebih rendah dibandingkan jenis lumut Jungermannia sp dan Sphagnum sp.

c. Sphagnum sp

Klasifikasi Sphagnum sp

$\begin{array}{ll}\text { Kerajaan } & : \text { Plantae } \\ \text { Divisi } & : \text { Bryophyta } \\ \text { Kelas } & : \text { Bryopsida } \\ \text { Ordo } & : \text { Sphagnales } \\ \text { Famili } & : \text { Sphagnaceae } \\ \text { Genus } & : \text { Sphagnum } \\ \text { Spesies } & : \text { Sphagnum sp }\end{array}$

Sphagnum sp terdiri atas family sphagnaceae dan genus sphagnum sp termasuk ke dalam kelompok lumut daun. Family dari sphagnum ini meliputi sejumlah besar jenis lumut yang kebanyakan hidup di tempat yang berawa-rawa dan membentuk rumpun atau bantalan yang tiap tahun bertambah luas sedangkan yang berada dibagian bawah mati dan berubah menjadi gambut, mempunyai batang banyak cabang dan cabangcabang yang muda tumbuh tegak membentuk roset pada ujungnya. Daun-daunnya yang sudah tua menjadi terkulai dan membalut bagian bawah batang. Cabang yang berada dibawah pucuk tumbuh cepat sama seperti induk batang, sehingga batang pada lumut tersebut kelihatan seperti bercabang menggarpu karena batang yang berada pada bagian bawah mati sedikit, menyebabkan cabang-cabang tersebut menjadi tumbuhan yang tumbuh secara terpisah-pisah (Tjitrosoepomo, 1998).

\section{Lumut hati (Hepaticeae)}

\section{a. Jungermannia $\mathrm{sp}$}

Klasifikasi Jungermannia sp 


$\begin{array}{lll}\text { Kerajaan } & : & \text { Plantae } \\ \text { Divisi } & : & \text { Marchantiophyta } \\ \text { Kelas } & : & \text { Jungermanniaopsida } \\ \text { Ordo } & : & \text { Jungermanniales } \\ \text { Famili } & : & \text { Jungermanniaceae } \\ \text { Genus } & : & \text { Jungermannia } \\ \text { Spesies } & : & \text { Jungermannia } \mathrm{sp}\end{array}$

Famili Jungermanniaceae terdiri atas 5 marga yang tersebar di daerah beriklim sedang, sebagian kecil tumbuh di daerah tropis. Spesies di suku ini merupakan lumut hati yang memiliki daun. Talus tumbuh membulat dan silindris yang di tumbuhi oleh 2 atau 3 baris daun dengan lembaran tipis berwarna hijau. Suku ini terdiri dari marga Eremonotus, Hattoriella, Jungermannia, Leiocolea, dan Mesoptychia. Kelima marga ini awalnya masuk ke dalam suku lain, tetapi berdasarkan hasil penelitian DNA, beberapa marga di golongkan ke dalam suku Jungermanniaceae. Genus Jungermannia terdiri dari 29 spesies yang tersebar di Amerika Utara sampai Amerika Selatan, Greenland, Eropa bagian barat, Madagaskar, Afrika bagian barat, Cina selatan dan barat serta Selandia Baru. Marga Jungermannia berasal dari nama seorang botanis asal Jerman, yaitu Ludwig Jungermann. Ia meneliti beragam spesies lumut yang ada di dunia terutama di Eropa, sebagai penghargaan atas jasanya, namanya pun di abadikan menjadi nama marga, nama suku, serta bangsa dan kelas lumut hati (Suhono et al, 2012).

b. Monoclea forsteri

Klasifikasi Monoclea forsteri

$\begin{array}{lll}\text { Kerajaan } & : & \text { Plantae } \\ \text { Divisi } & : & \text { Marchantiophyta } \\ \text { Kelas } & : & \text { Marchantiopsida } \\ \text { Ordo } & : & \text { Marchantiales } \\ \text { Famili } & : & \text { Monoleaceae } \\ \text { Genus } & : & \text { Monoclea } \\ \text { Spesies } & : & \text { Monoclea forsteri }\end{array}$

Monoclea forsteri adalah lumut hati besar dan thallus berwarna hijau gelap atau warna hijau zaitun, panjang talus mencapai $20 \mathrm{~cm}$ dan lebar $5 \mathrm{~cm}$, becabang secara dikotomi pada interval, strukturnya tidak beraturan dengan beberapa bagian tumbuh diatas yang lain. Tumbuhan jantan dapat dikenali oleh rumpun anteridial yang membengkak dan permukaan ventral dan pada permukaan dorsal tampak sebagai bantalan terpotong dengan tepi posterior (bagian belakang) yang agak menonjol terletak di garis median pada thallus, sedangkan pada tumbuhan betinanya berbentuk labu berlubang terjadi di titik tengah setiap lobus dan menyebabkan pada permukaan ventral, rongga hingga 1,5 hingga $2 \mathrm{~cm}$, panjang 3 sampai $5 \mathrm{~mm}$, lebar di pangkalnya, menyempit ke lubang pori kecil di permukaan dorsal thallus. Terletak di wadah lantai rongga yaitu 6 sampai 13 arkegonia bercampur dengan rambut lendir yang ramping, 
kemudian sporagonia matang dari mulut rongga dan di udara kering dan kapsul terbuka oleh celah tunggal pada permukaan ventral. Talus vegetatif tidak memiliki pelepah yang jelas tetapi sekitar 10 sel menebal di daerah pusat dan menipis ke kedalaman 1 hingga 4 sel menuju tepi, bantalan daun lebih tebal dan rhizoid muncul di seluruh permukaan bawah talus (Carafa et al, 2003).

\section{3. lumut kerak (Lichen)}

\section{a. Lepraria incana}

Klasifikasi Lepraria incana

$\begin{array}{lll}\text { Kerajaan } & : & \text { Fungi } \\ \text { Divisi } & : & \text { Ascomycota } \\ \text { Kelas } & : & \text { Lecanoromycetes } \\ \text { Ordo } & : & \text { Lecanorales } \\ \text { Famili } & : & \text { Stereocaulaceae } \\ \text { Genus } & : & \text { Lepraria } \\ \text { Spesies } & : & \text { Lepraria incana }\end{array}$

Morfologi dari Lepraria incana yaitu talus, berwarna merah, kuning, abu-abu, abuabu kehijauan, biru-kehijauan, orange, coklat medulla jarang hadir, tipis, krustosa (kulit luar) yang mendatar dan menempel pada substrat, berukuran kecil tidak beraturan dan tidak tentu, soredia melekat erat pada substrat membentuk lapisan tipis, lobus tidak jelas, permukaan atas abu-abu-hijau, biru-hijau, atau abu-abu-biru kusam, sedangkan ekologi dari lepraria incana yaitu : spesies ini banyak ditemukan di hutan konifer dengan berbagai pencahayaan dan kelembaban, spesies ini paling banyak di distribusikan dan paling umum di dalam genus di Belarusia dengan lokasi yang tersebar di bagian Utara dan Timur. Lepraria incana adalah lumut kosmopolitan yang di laporkan dari semua Benua kecuali daerah Arktik dan Antartika (Saag et al ,2009).

b. Parmelia $s p$

Klasifikasi Parmelia sp

$\begin{array}{lll}\text { Kerajaan } & : & \text { Fungi } \\ \text { Divisi } & : & \text { Ascomycota } \\ \text { Kelas } & : & \text { Lecanoromycetes } \\ \text { Ordo } & : & \text { Lecanorales } \\ \text { Famli } & : & \text { Parmeliaceae } \\ \text { Genus } & : & \text { Parmelia } \\ \text { Spesies } & : & \text { Parmelia } \mathrm{sp}\end{array}$

Parmelia sp tergolong dalam lichen yang toleran terhadap bahan pencemar udara, Parmelia sp memiliki sturktur morfologi yang mendukung untuk dapat bertahan hidup pada kondisi dengan tingkat polutan yang tinggi di bandingkan dengan jenis Lichen yang lain. Struktur parmelia sp terdiri dari korteks atas pada daerah alga, medulla, dan korteks bawah berupa rhizines. Rhizines berfungsi sebagai alat untuk mengabsorsi makanan bagi lichen, sehingga Lichen Parmelia dapat tumbuh dengan baik walaupun 
JURNAL HUTAN LESTARI (2019)

Vol. 7 (3) : 1035 - 1047

berada pada lingkungan yang tercemar dan sebagai perintis pada kondisi lingkungan yang ekstrim, Parmelia sp merupakan jenis yang toleran, Parmelia yang ditemukan termasuk ke dalam Corticulous lichen berkembang di permukaan atau batang pohon dan tergantung pada kestabilan pohon, tekstur, ph dan ketersediaan air. Permukaan pada lumut ini kasar dan terdapat spora atau diaspora vegetatif dan menyediakan kelembaban dalam waktu yang lama (Barreno, 2003).

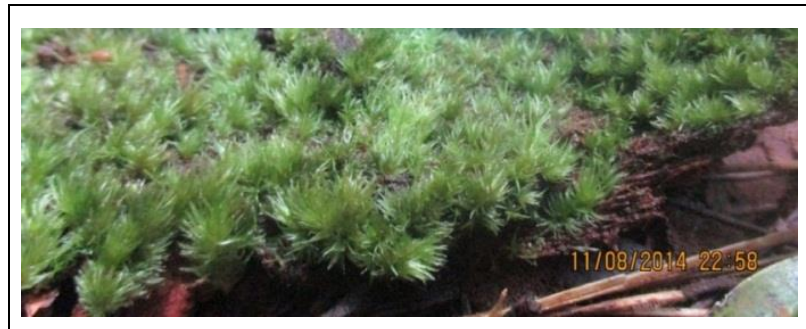

Gambar 1. Brachymenium indicum

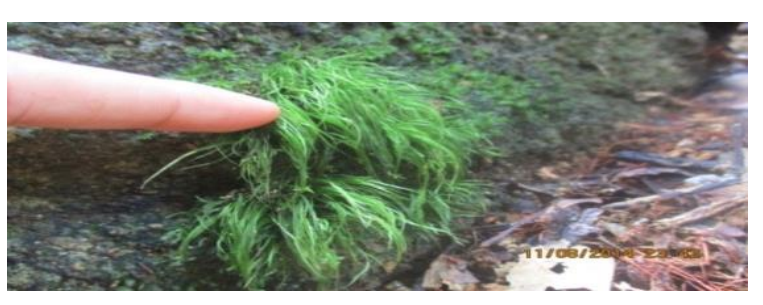

Gambar 2. Dicranella sp

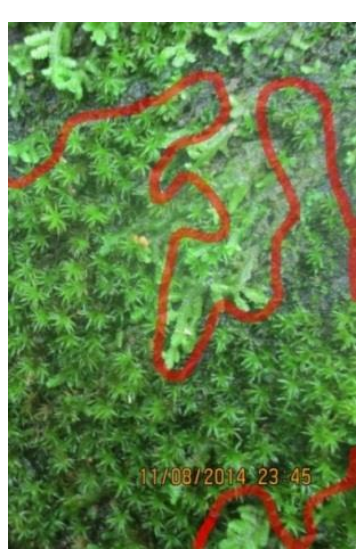

Gambar 3. Sphagnum sp

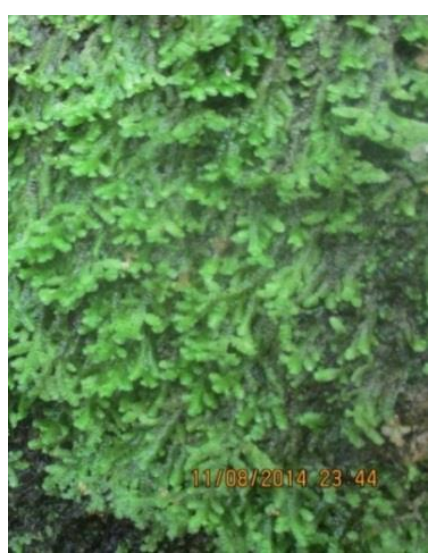

Gambar 4. Jungermannia sp

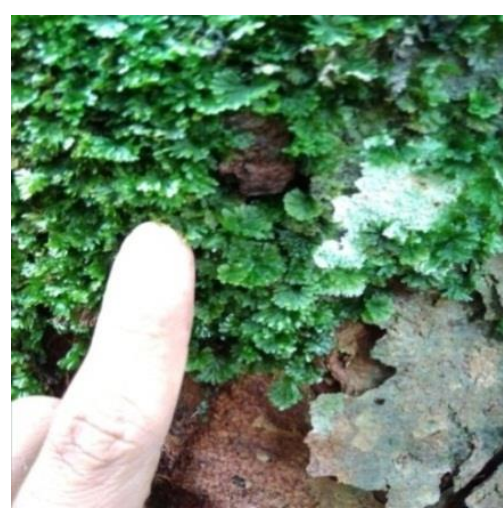

Gambar 5. Monoclea forsteri

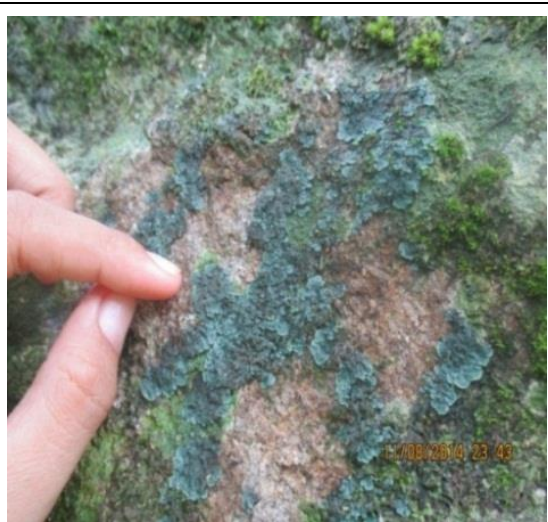

Gambar 6. Lepraria incana 


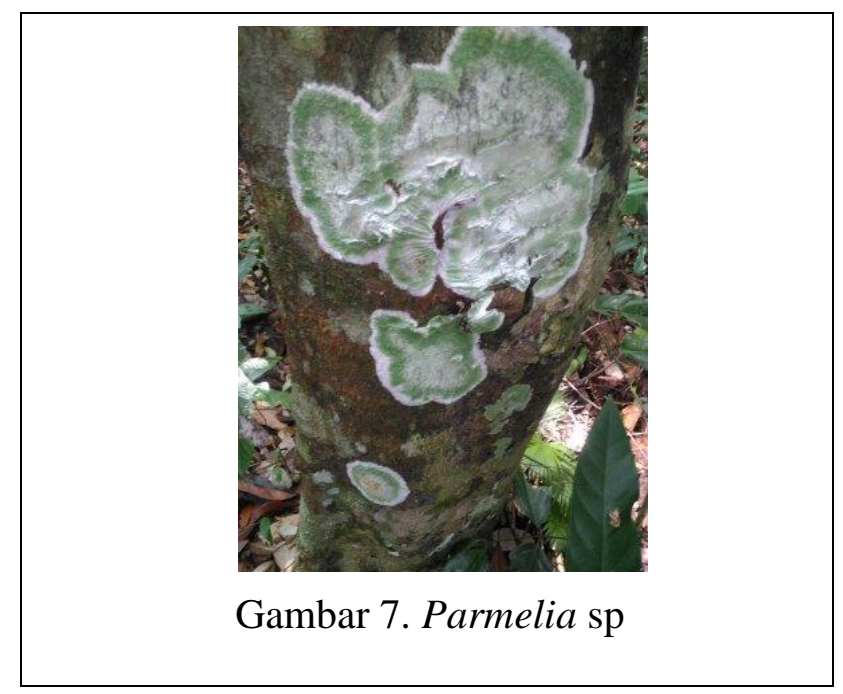

\section{KESIMPULAN}

Hasil penelitian dapat disimpulkan sebagai berikut.

1. Jenis lumut yang ditemukan pada kawasan hutan adat Bukit Benuah yaitu ada 7 jenis dari 3 kelas yaitu jenis lumut Brachymenium indicum, Dicranella sp, Sphagnum sp termasuk ke dalam kelas (lumut daun), Jungermannia sp dan Monoclea forsteri termasuk ke dalam kelas (lumut hati), Lepraria incana dan Parmelia sp termasuk ke dalam kelas (lumut kerak).

2. Jenis tumbuhan lumut yang mendominasi ada 3 jenis yaitu Brachymenium indicum dan Sphagnum sp dari kelas lumut daun dan Jungermannia sp dari kelas lumut hati.

3. Kondisi lingkungan yang mendukung pertumbuhan lumut pada kawasan hutan adat Bukit Benuah dengan rata-rata suhu $22^{\circ} \mathrm{C}$, kelembaban $80,66 \%$ dan intensitas cahaya yang masuk $77,34 \%$.

\section{SARAN}

Pada penelitian selanjutnya diharapkan dapat menambah pada ketinggian tempat dan luasan lokasi tempat penelitiann sehingga dapat menemukan lebih banyak lagi jenisjenis lumut dengan kondisi iklim lingkungan yang berbeda dan tingkatan jenis lumut yang lebih mendominasi.

\section{DAFTAR PUSTAKA}

Barreno E. 2003. Lichens as Bioindicators of Forest Health, Biodiversity and Ecological Continuity. Spanyol : Universitat de Valencia.

Carafa A, JG Duckett \& R Ligrone. 2003. The placenta in monoclea forsteri Hook and Treubia lacunosa (Col) Prosk: Insights Into Placental Evolution in Liverworts. Annals of Botany. 92: 299-307.

Damayanti L. 2006. Koleksi Bryophyta. Bogor : Taman Lumut Kebun Raya Cibodas. LIPI. 
Febrianti GN. 2015. Identifikasi Tumbuhan Lumut (Bryophyta) di Lingkungan Universitas Jember serta Pemanfaatannya Sebagai Buku Nonteks. Jatim: Universitas Jember.

Indrawan M, Primack RB, Supriatna J. 2007. Biologi Konservasi. Jakarta: Yayasan Obor Indonesia.

Nirwani, Zainab. 2010. Keanekaragaman Tumbuhan Bawah yang Berpotensi Sebagai Tanaman Obat di Hutan Taman Nasional Gunung Leuser Sub Seksi Bukit Lawang. Universitas Negeri Sumatera Utara. Medan.

Pasaribu N. 2013. Studi Pendahuluan Lumut di Lau Kawar Kabupaten Karo. Sumatera Utara: Universitas Sumatera Utara.

Saag L, Saag A dan Randle T. 2009. World survey of the genus lepraria (stereocaulaceae, lichenized ascomycota) in Bolorus. Folia Cryptog. 53: 4550.

Suhono Budi, Yersy Wulan, Penyunting. 2012. Ensiklopedia Biologi Dunia Tumbuhan Eksiklopedia Lumut. Ed ke-6. Jakarta: PT Lentera Abadi.

Tjitrosoepomo, 1989. Taksonomi Obat - Obatan. Yogyakarta: Gajah Mada University Press.

UU No. 5 Tahun 1960 tentang Peraturan Dasar Pokok-Pokok Agraria.

Windadri FI. 2014. Lumut Sejati Di Kawasan Cagar Alam Gunung Papandayan. Bogor: Berita Biologi 13 (3): 309-320. 